\title{
The Effectiveness of Being Success Learning Model in Computer Systems Subjects at Vocational High Schools
}

\author{
Rahmat Mahmud ${ }^{2}$, Syahrul², Riana T Mangesa \\ ${ }^{1}$ Department of Vocational Education and Engineering, Universitas Negeri Makassar \\ Jln. Bonto Langkasa Kampus Gunung Sari Baru, Makassar, Indonesia \\ ${ }^{1}$ SMK Telkom, Makassar, Indonesia \\ Email: rhm168 [AT] gmail.com \\ ${ }^{2}$ Department of Engineering, Universitas Negeri Makassar \\ Jln. Daeng Tata Raya, Makassar, Indonesia \\ Email: syahrul [AT] unm.ac.id \\ ${ }^{3}$ Department of Engineering, Universitas Negeri Makassar \\ Jln. Daeng Tata Raya, Makassar, Indonesia \\ Postal Code 90224 \\ Email: riana.tangkin [AT] unm.ac.id
}

\begin{abstract}
This study aims at determining the effectiveness of the Being Success model in improving student learning outcomes in Computer Systems subjects at Vocational High Schools (SMK). This study uses a quasi-experimental comparative quantitative approach with a pre-test post-test control group design as the research design. This study was conducted at SMKN 05 Makassar and SMKS Telkom Makassar on January 22 to April 22, 2021. The population in this study was class $X$ students on the even semester with the field of Information and Communication Technology expertise in Computer Systems subjects for the 2020/2021 academic year. Subject selection was carried out purposively with certain considerations. Basic Competencies (KD) suitability and the consistency of subjects to participate in online learning activities during the pandemic are considered. Therefore, the subjects in this study involved two classes with 54 students consisting of 27 students of class X SMKN 05 Makassar as the experimental class and 27 students of class X SMKS Telkom Makassar as the control class. Data were obtained from the results of the pre-test and post-test in the form of multiplechoice questions. Furthermore, the data were analyzed using parametric t-test statistics with a significance level of 0.05 . Based on the output of the Independent sample sig (2-tailed), the t-test was $0.000<0.05$. These results indicate that there is a significant difference in the acquisition of learning outcomes between the control class and the experimental class. It can be concluded that $\mathrm{H}_{0}$ is rejected and $\mathrm{H}_{1}$ is accepted. Based on the results of the calculation of the N-Gain Score from the pre-test and post-test values, the normalized gain value for the experimental class was 0.73 , and the control class was 0.58 . The values obtained are then interpreted into the normalized gain value criteria (N-Gain); from these values, it can be concluded that the effectiveness of the application of the Being Success model in the experimental class is in the high category.
\end{abstract}

Keywords - Pattern of interaction, activity, blended learning, effective

\section{INTRODUCTION}

This study is from the findings of the Indonesian Child Protection Commission (KPAI) and the Federation of Indonesian Teachers' Unions (FSGI) regarding the Implementation of Distance Learning (PJJ) during the pandemic. These findings indicate that 76.7 per cent of students are not happy to participate in the Implementation of Distance Learning because several aspects include the heavy task assigned by the teachers. The survey also found that 81.8 per cent of students were only limited to doing assignments and minimal discussion or getting material, and 77.6 per cent of teachers were more oriented towards 
assessment activities compared to learning activities [1]. This finding proves that the ability of the teacher to select and determine appropriate patterns of interaction, activities and learning resources, both synchronous and asynchronous in accordance with learning objectives, is still low, limited to giving assignments and evaluations. Meanwhile, students expect more direct guidance and interaction from teachers in online learning activities.

Based on the Regulation of the Minister of Education and Culture of the Republic of Indonesia Number 103 in 2014 concerning Learning in Basic Education and Secondary Education, articles (1) and (2) state that learning is a process of interaction between fellow students and teachers as well as interaction with sources or learning environment. Learning activities consist of: interactive; inspiration; pleasant; challenge; can motivate students; can activate student participation; contextual and collaborative; provide opportunities for creativity and independence of students according to their talents, interests, and abilities, as well as their physical and psychological development. Learning should use approaches, strategies, models, and methods to create a learning environment to allow the learning process to occur to achieve a predetermined competency [2].

The process of learning interaction in vocational school has undergone radical changes during the COVID-19 pandemic and the new normal. Currently, in the vocational school environment, it is required to organize a learning process that can produce effective interactions between teachers, students, and learning resources through various approaches by utilizing online learning platforms. In the national system of teachers (SNP), it is stated that one approach that is believed to be able to establish an effective interaction process between components in the vocational school environment is student-centred learning. This approach is a learning approach of the 2013 Curriculum, clearly stated in the Regulation of the Minister of Education and Culture No. 81A regarding the Implementation of the 2013 Curriculum. Through this approach, interaction in the learning process will be able to encourage the spirit of learning, motivation, interest, creativity, initiative, inspiration, innovation and independence [3].

Patterns of interaction, activities, and learning resources which are important components in the learning process, need to be corrected immediately. Blended learning is the main choice recommended by the government and experts in the field of education. Conceptually, blended learning is not just combining synchronous and asynchronous learning processes. In this case, it is extended to how to integrate various learning resources and appropriate learning activities where students can interact and build ideas with each other [4]. Blended learning is believed to be able to create a positive learning environment for interactions between fellow students and students and their teachers without being limited by space and time [5-7]. Interaction between students, students and teachers is a key factor in the learning process for students and is an important element in creating an effective learning experience [8]. The interaction process between teachers, students, and the learning environment will result in changes in behaviour, learning outcomes, and students' thinking abilities [9].

Blended learning is a term introduced by the distance learning community as an effort to utilize synchronous learning activities, such as face-to-face interactions with teachers and collaborative work with peers as a complement to asynchronous learning activities carried out individually by students [10]. A similar understanding explains that blended learning is a combination of components from synchronous and asynchronous learning aspects with the aim of achieving maximum learning effectiveness [11] . Thus, blended learning can be viewed from the perspective of synchronous and asynchronous learning settings. In essence, blended learning can be said to be a combination of synchronous learning that occurs simultaneously and asynchronous learning that occurs at different times and places.

Seeing the capabilities possessed by the blended learning model and this radical change in the learning environment, the use of the blended learning model is deemed appropriate and can be used as an alternative learning model that is able to combine synchronous and asynchronous learning processes. In its application, the learning process is said to be effective if, in implementing a learning model, it is able to deliver students to achieve maximum learning outcomes. Blended learning is a learning environment that is structured with the intention of obtaining maximum results [12] and is proposed as a didactic strategy to improve learning activities in the classroom because it is successful in increasing the knowledge and skills of students [7]. Furthermore, the use of the blended learning model also aims to increase opportunities for students to learn independently [13].

Blended learning can create new learning activities that provide new learning situations that have not been widely practised before. Many experts and practitioners have also proven the effectiveness of applying blended learning in achieving learning objectives. With Blended learning, it is hoped that students will not only achieve the specific learning objectives that have been set. But at the same time triggering the creativity of students and bringing them closer to technology that has become a daily necessity.

This is what underlies this development research, which focuses on developing an interactive blended learning model by combining synchronous and asynchronous learning activities in such a way as to create an optimal learning experience in order to achieve the learning objectives that have been determined. The rationale for developing this blended learning model refers 
to Ausubel's opinion. Ausubel argues that teachers must be able to develop the cognitive potential of students through a meaningful learning process. Ausubel assumes that students' learning activities at the basic education level will be beneficial if they are widely involved in direct activities [14].

The learning model developed is named Blended Learning Success, abbreviated as Being Success using an online learning platform based on LMS (Learning Management System) via Moodle (Modular Object-Oriented Dynamic Learning). This learning model combines the use of technology and appropriate learning methods in order to create an active and constructive learning environment in which information and communication technology is the vehicle for making decisions learning events occur optimally. This learning model combines various blended learning implementation strategies with relevant interaction patterns and synchronous and asynchronous learning activities and maximizes social media functions for confirmation, monitoring, discussion, and communication in learning activities. The pattern of interaction and activity in learning can be seen in the following figure:

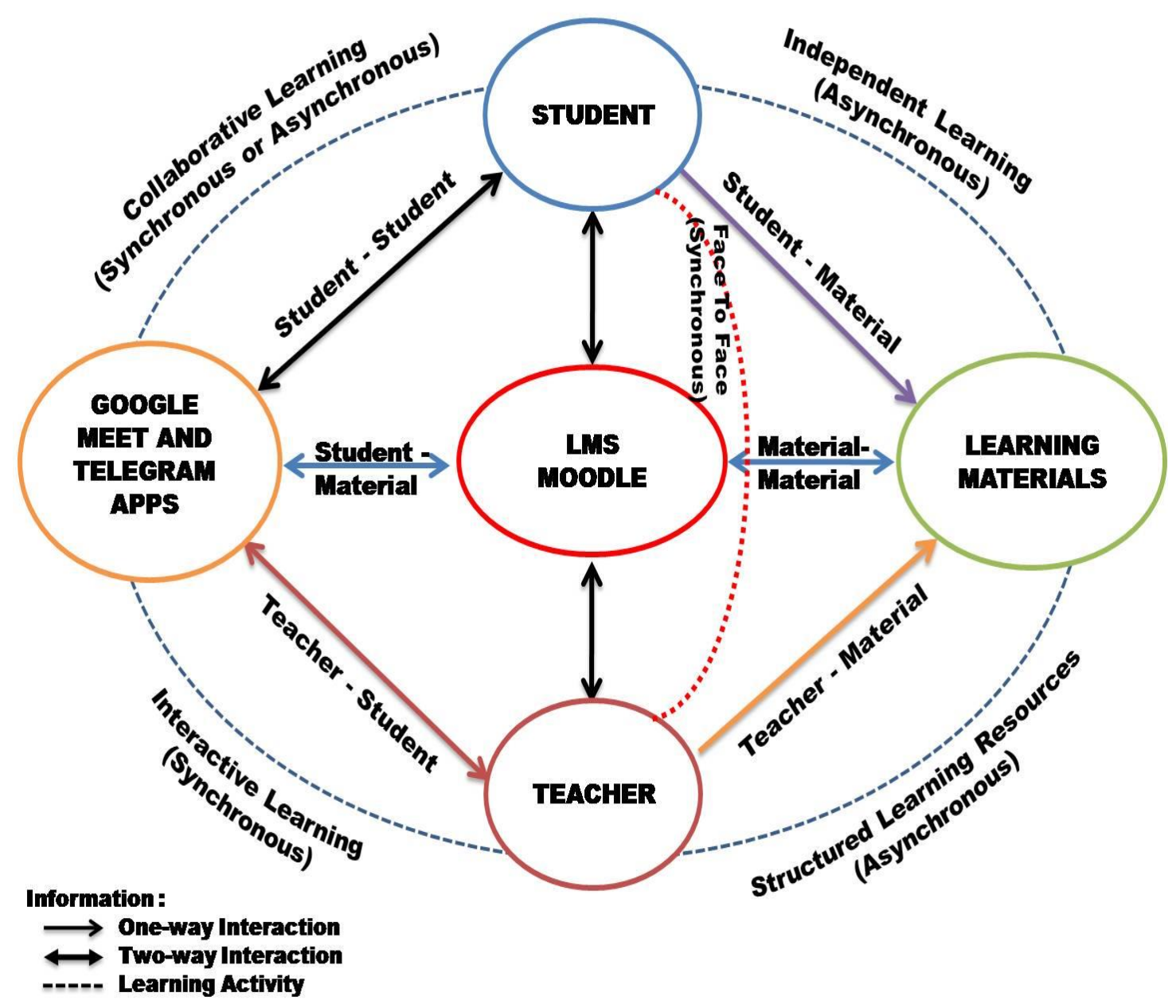

Figure 1. Being Success. interaction and activity patterns

This interaction pattern is Anderson's online learning interaction pattern [15], combined with the learning experience cone by Edgar Dale [16], with learning activities proposed by [17] and [18]. The Being Success learning model is a learning model that supports the 2013 curriculum learning model that has been set by the Ministry of Education and Culture of the Republic of Indonesia. This model is expected to improve student learning outcomes as an instructional impact and empower 21st-century skills (Communication, Collaboration, Critical thinking, and Creativity) students that appear as an accompaniment impact. This learning model will be tested on Computer Systems subjects in a vocational school environment.

\section{RESEARCH METHODS}

This study uses a comparative quantitative approach to quasi-experimental design, which aims to determine the effectiveness 
of the use of the Being Success model on improving student learning outcomes. The research design used was pre-test posttest control group design. In this design, there are two groups, namely the control and experimental groups, which are then given a pre-test before participating in learning activities or at the beginning of basic competencies to help determine equality before treatment and post-tests are given at the end of learning activities or basic competencies after students receive treatment. The Being Success model aims to find out whether there are differences between the two groups. This experimental model is described as follows:

Table 1. Research Design

\begin{tabular}{cccc}
\hline Class & Pre-test & Treatment & Post-test \\
\hline Experiment & $O_{1}$ & $X_{1}$ & $O_{2}$ \\
\hline Control & $O_{3}$ & $X_{2}$ & $O_{3}$ \\
\hline
\end{tabular}

Description:

$O_{1}$ value of the experimental class before treatment,

$\mathrm{O}_{2}$ value of the experimental class after treatment

$X_{1}$ is a treatment using the Being Success model

$\mathrm{O}_{3}$ value of control class before treatment,

$\mathrm{O}_{4}$ value of control class after treatment

$X_{2}$ is a treatment using an online method

The study process begins by establishing a control class and an experimental class. The control class uses the online method $\left(\mathrm{X}_{2}\right)$, and the experimental class applies the Being Success model $\left(\mathrm{X}_{1}\right)$. The effectiveness of the treatment was obtained from the average difference between the pre-test and post-test in each control and experimental class. Before calculating the effectiveness of the treatment, statistical tests were carried out on the data obtained. To find out whether the data obtained were normally distributed and homogeneous, a parametric test was performed using the Shapiro-Wilk t-test method. A good and proper data to be used in research is data with a normal and homogeneous distribution. However, if the data obtained are not normally distributed and homogeneous, it will be continued with the non-parametric Wilcoxon method test. Furthermore, hypothesis testing and $\mathrm{N}$-gain score test was carried out to determine the difference between the average and the effectiveness of a research hypothesis.

This study was conducted at SMKN 05 Makassar and SMKS Telkom Makassar on January 22 to April 22, 2021. The population in this study was students of class X even semester in the field of Information and Communication Technology expertise in Computer Systems subjects for the 2020/2021 academic year. Subject selection was carried out purposively with certain considerations. Basic Competencies suitability and the consistency of subjects in participating in online learning activities during the pandemic are considered. The subjects used in this study consisted of 2 classes totalling 54 students consisting of 27 students of class X SMKN 05 Makassar as the experimental class, and 27 students of class X SMKS Telkom Makassar as the control class.

\section{RESULTS}

Observation on the use of the Being Success model was conducted to determine the competence of students' learning

\subsection{Statistical Test}

Table 2. Tests of Normality

\begin{tabular}{cccccccc}
\hline \multirow{2}{*}{ Class } & \multicolumn{3}{c}{ Kolmogorov-Smirnova } & \multicolumn{3}{c}{ Shapiro-Wilk } \\
\cline { 2 - 8 } & Statistic & $d f$ & Sig. & Statistic & $d f$ & Sig. \\
\hline \multirow{3}{*}{$\begin{array}{l}\text { Learning } \\
\text { Outcomes }\end{array}$} & Prest $K$ & .144 & 27 & .157 & .949 & 27 & .207 \\
\cline { 2 - 8 } & Post-Test $K$ & .165 & 27 & .058 & .949 & 27 & .208 \\
\cline { 2 - 8 } & Pre-Test $E$ & .160 & 27 & .074 & .961 & 27 & .389 \\
\cline { 2 - 8 } & Post-Test $E$ & .161 & 27 & .072 & .954 & 27 & .265 \\
\hline \multicolumn{3}{c}{ a. Lilliefors Significance Correction } \\
\hline
\end{tabular}

Before testing the hypothesis, it is necessary to test the data to be used whether it meets the requirements for testing the hypothesis or not. The tests carried out are normality and homogeneity tests. The normality test was conducted to determine whether the data in the variables to be analyzed were normally distributed. The normality test was carried out using the ShapiroWilk test. The results of this normality test can be seen in Table 2 . 
The basis for decision making in the Shapiro-Wilk normality test is if the significance value (Sig.) $>0.05$, then the data is said to be normally distributed. Based on the normality test results above, the value of Sig. for the pre-test and post-test in the control and experimental groups $>0.05$, it can be concluded that the data are normally distributed. Furthermore, a homogeneity test will be carried out to determine whether the data obtained from the two classes have homogeneous variants or not. The results of the homogeneity test are presented in Table 3.

Table 3. Test of Homogeneity of Variance

\begin{tabular}{cccc}
\hline Levene Statistic & $d f 1$ & $d f 2$ & Sig. \\
\hline .154 & 3 & 104 & .927 \\
\hline
\end{tabular}

The basis for decision making in the homogeneity test is if the significance value (Sig.) $>0.05$, it can be said that the data meets the assumption of homogeneity. Based on the homogeneity of variance test results above, it can be seen that the significant value of the pre-test and post-test in the experimental class based on the pre-test and post-test in the control class is $0.927>$ 0.05. This means that the experimental class's pre-test and post-test data based on the control class's pre-test and post-test data have the same variance (homogeneous).

\subsection{Hypothesis Test}

This hypothesis test uses an independent sample t-test that aims to determine the difference between two variables, namely the difference in learning outcomes between the experimental and control classes. Before testing the hypothesis, the hypothesis is formulated as follows; H0: there is no difference in learning outcomes between the experimental class and the control class, and $\mathrm{H} 1$ : there is a difference in learning outcomes between the experimental class and the control class. If the probability value or Sig. (2-tailed) $<0.05$, then H0 is rejected, H1 is accepted, and the probability value or Sig. (2-tailed) $>0.05$, then H0 is accepted, and $\mathrm{H} 1$ is rejected. The results of this test can be seen in Table 4 below.

Table 4. Independent Samples Test

\begin{tabular}{cccccccc}
\hline & \multicolumn{3}{c}{$\begin{array}{c}\text { Levene's Test for } \\
\text { Equality of } \\
\text { Variances }\end{array}$} & \multicolumn{4}{c}{ t-test for Equality of Means } \\
\cline { 2 - 8 } & $F$ & Sig. & $t$ & $d f$ & $\begin{array}{c}\text { Sig. } \\
\text { (2-tailed) }\end{array}$ & $\begin{array}{c}\text { Mean } \\
\text { Difference }\end{array}$ \\
\hline \multirow{2}{*}{$\begin{array}{c}\text { Learning } \\
\text { Outcomes }\end{array}$} & $\begin{array}{c}\text { Equal variances } \\
\text { assumed }\end{array}$ & .017 & .896 & -3.990 & 52 & .000 & -8.889 \\
\cline { 2 - 8 } & $\begin{array}{c}\text { Equal variances not } \\
\text { assumed }\end{array}$ & & & -3.990 & 51.904 & .000 & -8.889 \\
\hline
\end{tabular}

Based on the results of the independent sample t-test, the probability value or sig (2-tailed) was $0.000<0.05$. These results indicate that there is a significant difference in the acquisition of learning outcomes between the control class and the experimental class. It can be concluded that $\mathrm{H} 0$ is rejected and $\mathrm{H} 1$ is accepted.

\subsection{Test N-Gain Score}

The N-Gain Score test was conducted to determine the increase in student learning outcomes after being given treatment. The $\mathrm{N}-$ Gain score is done by calculating the difference between the post-test scores and the pre-test scores. The results obtained are used to determine whether the use of a particular method can be said to be effective or not. The results of the calculation of normalized gain $(\mathrm{g})$ in the experimental and control classes can be seen in Table 5.

Table 5. The results of the calculation of the N-Gain Score of the experimental class and the index of the control class

\begin{tabular}{ccccc}
\hline Class & Pre-test & Post-test & Gain & N-Gain \\
\hline Control & 32.41 & 72.22 & 39.81 & 0.58 \\
\hline Experiment & 30.00 & 81.11 & 51.11 & 0.73 \\
\hline
\end{tabular}

Based on the results of the calculation of the N-Gain score from the pre-test and post-test values, the normalized gain value for the experimental class was 0.73 , and the control class was 0.58 . The values obtained are then interpreted into the normalized gain value criteria (N-Gain); from these values, it can be concluded that the effectiveness of the application of the Being Success 
model in the experimental class is in the high category.

\section{DISCUSSION}

Indicators to state that the implementation of a learning model is said to be effective can be seen, one of which is student learning outcomes. Based on the results of the independent sample t-test and the gain value, there were significant learning outcomes between the control class and the experimental class; this proves that the Being Success learning model applied to computer system subjects is effective in improving learning outcomes. The results of this study are in line with the results of research, which found that blended learning can show bigger differences in terms of motivation, interest, and student learning outcomes [19]. Other researchers conclude that the blended learning model is effective for improving students' learning achievement $[20,21]$.

This computer system learning is held online using the being success learning model, so participants are also required to understand how to operate the necessary online learning tools. The previous findings prove that if blended learning can be implemented properly and correctly, then there are three benefits that can be obtained, namely: 1) improving learning outcomes through distance education, 2) increasing the ease of learning so that students become satisfied in learning through distance education, and, 3) reducing learning costs [22].

Other results from this study indicate an increase in interaction between students and learning materials in the form of independent learning activities on the virtual computer system learning portal. Students are more active in participating in learning activities with teachers using video conference applications and collecting assignments. Collaboration between students is more active seen in social media groups. Therefore, it can be said that the Being Success learning model can improve student interactions and activities. This is in line with the findings of several researchers that one of the advantages of blended learning is to increase interaction between students, between students and teachers, and students with various learning resources, anytime and anywhere, without being limited by space and time [5-7]. Researchers suggest that interaction between students and interaction between students and teachers is a key factor in students' learning process and is an important element in creating an effective learning experience.

Empirically the results of field trials also show that the Being Success learning model meets the practical criteria applied to computer systems subjects in terms of indicators of the implementation of learning activities by teachers and students as well as the ability of teachers to manage to learn. These results are in accordance with the expert opinion, which states that the practical aspects can be seen from the user's point of view: (1) whether the practitioners think that what has been developed can be applied; and (2) whether the fact shows that what has been developed can be applied by teachers and students [23].

The application of the Being Success learning model in computer systems subjects received positive responses from both teachers and students. This positive response was in line with the experts [24-27], stating that blended learning is preferred over traditional classes because blended learning provides satisfaction. This study also discusses the effect of performance expectations, business expectations factors, social factors, and conditions that facilitate the acceptance behaviour of the Being Success learning model.

The results of hypothesis testing also show that of the four factors studied; there are two factors, namely performance expectations and social factors, on behavioural intentions to use the system that have a positive and significant effect. This is in line with the findings of several previous researchers who showed that blended learning resulted in a stronger sense of community among students than traditional learning [28]. Experts also suggest that the interaction between students and the interaction between students and teachers is a key factor in students' learning process and is an important element in creating an effective learning experience $[8,29][8,29]$. While the factors of business expectations and facilitating conditions have a positive but not significant effect, this is also in line with several research results in America which show blended learning is very effective, compared to other learning, blended learning is 30\% better, $40 \%$ shorter time, and 30\% lower cost [30].

The results of the final product design of the Being Success learning model that has been developed are included in the "very feasible" category to be used in computer system learning according to the results of validation and suggestions from experts and practitioners. Thus, the developed Being Success learning model can be used to determine the ability of students in learning computer systems because the model is developed rationally in theory, and there is the internal consistency of learning material components with the Being Success learning model. This result is in line with the opinion of [23], which states that a learning model developed is said to be valid if the model is based on adequate theory (content validity) and all components of the learning model are consistently related to each other (construct validity). 


\section{CONCLUSION}

Based on the results of research and discussion, it can be concluded that the application of the Being Success learning model can improve student learning outcomes better than students who use online learning methods in Computer Systems subjects. These results indicate that the Being Success learning model in Computer Systems subjects in Vocational High Schools meets the effective criteria based on learning outcomes indicators.

\section{REFERENCES}

1. Tempo. Siswa Tak Menyukai Belajar Jarak Jauh - Nasional - koran.tempo.co. Tempo [Internet]. 2020 Apr 29 [cited 2021 Sep 23]; Available from: https://koran.tempo.co/read/nasional/452292/siswa-tak-menyukai-belajar-jarak-jauh

2. MENTERI PENDIDIKAN DAN KEBUDAYAAN REPUBLIK INDONESIA. Permendikbud Nomor 103 Tahun 2014.pdf [Internet]. $2014 \quad$ [cited $2021 \quad$ Sep 23]. Available from: https://jdih.kemdikbud.go.id/arsip/Permendikbud\%20Nomor\%20103\%20Tahun\%202014.pdf

3. Menteri Pendidikan Nasional. Abstrak Permendikbud nomor 81A Tahun 2013.pdf [Internet]. Permendikbud. 2013 [cited 2021 Sep 23]. Available from: https://jdih.kemdikbud.go.id/arsip/Abstrak\%20Permendikbud\%20nomor\%2081A\%20Tahun\%202013.pdf

4. Littlejohn A, Pegler C. Preparing for Blended E-Learning [Internet]. New York: Routledge; 2007. Available from: https://www.researchgate.net/publication/48990919_Preparing_for_Blended_E-Learning

5. Lalima, Dangwal KL. Blended Learning: An Innovative Approach. Universal Journal of Educational Research. 2017 Jan;5(1):129-36.

6. Osguthorpe RT, Graham CR. Blended Learning Environments: Definitions and Directions. Quarterly Review of Distance Education. 2003;4(3):227-33.

7. Sari M, Asmendri A. Analisis Model-model Blended Learning di Lembaga Pendidikan. Natural Science: Jurnal Penelitian Bidang IPA dan Pendidikan IPA. 2019 Sep 26;5(2):835-47.

8. Comey WL. Blended learning and the classroom environment: A comparative analysis of students' perception of the classroom environment across community college courses taught in traditional face-to-face, online and blended methods. [Columbia]: The George Washington University; 2009.

9. Maolidah IS, Ruhimat T, Dewi L. EFEKTIVITAS PENERAPAN MODEL PEMBELAJARAN FLIPPED CLASSROOM PADA PENINGKATAN KEMAMPUAN BERPIKIR KRITIS SISWA. Educational Technologia [Internet]. 2017 Aug 1 [cited $2021 \quad$ Sep 23];1(2). Available from: https://ejournal.upi.edu/index.php/edutechnologia/article/view/9147

10. Howard L, Remenyi Z, Pap G. Adaptive Blended Learning Environments. In Nashville: Vanderbilt University, Institute for Software Integrated Systems; 2006. Available from: https://ineer.org/Events/ICEE2006/papers/3083.pdf

11. Piskurich GM. Rapid Instructional Design: Learning ID Fast and Right [Internet]. 3rd Ed. USA: John Wiley \& Sons; 2015 [cited $2021 \quad$ Sep 24]. Available from: https://www.wiley.com/enht/Rapid+Instructional+Design\%3A+Learning+ID+Fast+and+Right\%2C+3rd+Edition-p-9781118973974

12. Garner B, Oke L. Blended Learning:Theoretical Foundation. Marion: Indiana Wesleyan University; 2014.

13. Darma IK, Karma IGM, Santiana IMA. Blended Learning, Inovasi Strategi Pembelajaran Matematika di Era Revolusi Industri 4.0 Bagi Pendidikan Tinggi. PRISMA, Prosiding Seminar Nasional Matematika. 2020 Feb 28;3:527-39.

14. Novak JD. A THEORY OF EDUCATION: MEANINGFUL LEARNING UNDERLIES THE CONSTRUCTIVE INTEGRATION OF THINKING, FEELING, AND ACTING LEADING TO EMPOWERMENT FOR COMMITMENT AND RESPONSIBILITY. Aprendizagem Significativa em Revista. 2011;1(2):14.

15. Anderson T, editor. The theory and practice of online learning. 2nd ed. Edmonton: AU Press; 2008. 472 p.

16. Dale E, Rinehart H, Winston. Audio-Visual Methods in Teaching [Internet]. 3rd Ed. New York: Dryden Press; 1969. Available from: https://www.researchgate.net/figure/Edgar-Dale-Audio-Visual-Methods-in-Teaching-3rd-EditionHolt-Rinehart-and-Winston_fig1_283011989

17. Horton WK. E-learning by design. San Francisco: Pfeiffer; 2006. 596 p.

18. Smaldino SE, Lowther DL, Mims C, Russel JD. Instructional Technology and Media for Learning. 12th Ed. London: Pearson Education Inc.; 2019.

19. Usman U. Komunikasi Pendidikan Berbasis Blended Learning Dalam Membentuk Kemandirian Belajar. Jurnal Jurnalisa: Jurnal Jurusan Jurnalistik. 2019;4(1).

20. Kurniawati M, Santanapurba H, Kusumawati E. PENERAPAN BLENDED LEARNING MENGGUNAKAN MODEL FLIPPED CLASSROOM BERBANTUAN GOOGLE CLASSROOM DALAM PEMBELAJARAN MATEMATIKA SMP. EDU-MAT: Jurnal Pendidikan Matematika [Internet]. 2019 Jul 24 [cited 2021 Sep 24];7(1). Available from: https://ppjp.ulm.ac.id/journal/index.php/edumat/article/view/6827 
21. Pratiwi D, Sugiharto, Mulyani B. EFEKTIVITAS MODEL BLENDED e-LEARNING COOPERATIVE APPROACH TIPE TGT DILENGKAPI MODUL TERHADAP PRESTASI BELAJAR KIMIA MATERI POKOK HIDROKARBON KELAS X SEMESTER II SMA NEGERI 5 SURAKARTA TAHUN AJARAN 2011/2012. Jurnal Pendidikan Kimia [Internet]. 2013 May 1 [cited 2021 Sep 24];2(1). Available from: https://jurnal.fkip.uns.ac.id/index.php/kimia/article/view/1130

22. Yendri D. BLENDED LEARNING: MODEL PEMBELAJARAN KOMBINASI E-LEARNING DALAM PENDIDIKAN JARAK JAUH - PDF Free Download [Internet]. adoc.pub. 2011 [cited 2021 Sep 24]. Available from: https://adoc.pub/blended-learning-model-pembelajaran-kombinasi-e-learning-dal.html

23. Akker JVD, Branch RM, Gustafson K, Nieveen N, Plomp T. Design Approaches and Tools in Education and Training [Internet]. 1st Ed. Netherlands: Springer Netherlands; 1999 [cited 2020 Mar 5]. Available from: https://ris.utwente.nl/ws/portalfiles/portal/14472302/Introduction_20to_20education_20design_20research.pdf

24. Bawaneh SS. The Effects of Blended Learning Approach on Students' Performance: Evidence from a Computerized Accounting Course. International Journal of Humanities and Social Science. 2011;1(6):7.

25. Husni A, Juanda EA, Hamidah I. Model Pembelajaran Kooperatif Berbantuan Web Pada Materi Fluida Statis Untuk Meningkatkan Pemahaman Konsep Siswa SMA. In: Prosiding Seminar Nasional Fisika. Bandung: Himpunan Fisika Indonesia Cabang Jawa Barat; 2010.

26. Levenberg A, Caspi A. Comparing Perceived Formal and Informal Learning in Face-to-Face versus Online Environments. IJELL. 2010;6:323-33.

27. Melton BF, Bland H, Chopak-Foss J. Achievement and Satisfaction in Blended Learning versus Traditional General Health Course Designs. ij-sotl [Internet]. 2009 Jan 1 [cited 2021 Sep 24];3(1). Available from: http://digitalcommons.georgiasouthern.edu/ij-sotl/vol3/iss $1 / 26$

28. Rovai AP, Jordan H. Blended Learning and Sense of Community: A Comparative Analysis with Traditional and Fully Online Graduate Courses. The International Review of Research in Open and Distributed Learning [Internet]. 2004 Aug 1 [cited 2021 Sep 24];5(2). Available from: http://www.irrodl.org/index.php/irrodl/article/view/192

29. Boydston JA. The Middle Works of John Dewey (Collected Works of John Dewey). 1st Ed. Vol. Vol. 9. Illinois: Southern Illinois University Press; 2008.

30. Rusman, Kurniawan D, Riyana C. Pembelajaran berbasis teknologi informasi dan komunikasi : mengembangkan profesionalitas guru. 1st Ed. Jakarta: Rajawali Pers; 2012. 